\author{
АНАЛІЗ МІЖНАРОДНОГО ДОСВІДУ РОЗВИТКУ \\ ВИСОКОШВИДКІСНИХ ЗАЛІЗНИЧНИХ ПЕРЕВЕЗЕНЬ \\ ТА ПИТАННЯ ЙОГО ВПРОВАДЖЕННЯ В УКРАЇНІ
}

\author{
ANALYSIS OF INTERNATIONAL EXPERIENCE FOR THE DEVELOPMENT \\ OF HIGH-SPEED RAILWAY TRANSPORT AND QUESTIONNAIRE \\ OF ITS IMPLEMENTATION IN UKRAINE
}

УдК 338.47:656.2(477)

https://doi.org/10.32843/infrastruct33-5

\section{Єрьоміна М.О.}

к.е.н., доцент кафредри управління державними і корпоративними

срінансами

Український державний університет залізничного транспорту

Тройнікова О.М.

к.е.н., доцент кафредри управління державними і корпоративними фрінансами

Український державний університет залізничного транспорту

Сапронова О.М.

магістр

Український державний університет залізничного транспорту

\begin{abstract}
У статті проаналізовано світовий досвід розвитку високошвидкісних залізничних перевезень. Досліджено вплив швидкісних та високошвидкісних перевезень на залучення пасажиропотоку й збільшення прибутку вітчизняних залізниць та залізниць розвинутих країн. Розглянуто проблеми та перспективи впровадження високошвидкісних залізничних пасажирських перевезень в Україні. Визначено, що запровадження високошвидкісного руху є найважливішим шляхом розвитку ринку залізничних пасажирських та вантажних перевезень на шляху до євроінтеграції, тому що для України євроінтеграція є головним і незмінним зовнішньополітичним пріоритетом, а подальша розбудова та поглиблення відносин між Україною та ЄС здійснюється на принципах політичної асоціації та економічної інтеграції. Але при цьому в найближчий час у залізничній галузі України впровадження високошвидкісних перевезень, ймовірно, буде проблематично. Це, перш за все, викликане специфрікою інфрраструктури для руху на таких швидкостях, а побудова ї у сучасних умовах не є простим завданням (різноманітний рельєфр, велика кількість кривих ділянок), та однією з найважливіших причин є фрінансові проблеми побудови.

Ключові слова: високошвидкісні залізничні пасажирські перевезення, залізничний транспорт, євроінтеграція, якість пасажирських перевезень, інфраструктура залізничного транспорту
\end{abstract}

В статье проанализирован мировой опыт развития высокоскоростных железнодо- рожных перевозок. Исследовано влияние скоростных и высокоскоростных перевозок на привлечение пассажиропотока и увеличение прибыли отечественных железных дорог и железных дорог в развитых странах. Рассмотрены проблемы и перспективы внедрения высокоскоростных железнодорожных пассажирских перевозок в Украине. Определено, что введение высокоскоростного движения является важнейшим направлением развития рынка железнодорожных пассажирских и грузовых перевозок на пути к евроинтеграции, потому что для Украины евроинтеграция является главным и неизменным внешнеполитическим приоритетом, а дальнейшее развитие и углубление отношений между Украиной и ЕС осуществляется на принципах политической ассоциации и экономической интеграции. Но при этом в ближайшее время в железнодорожной отрасли Украины внедрение высокоскоростных перевозок, вероятно, будет проблематично. Это, прежде всего, вызвано специфрикой инфраструктуры для движения на таких скоростях, а ее строительство в современных условиях является не простой задачей (разнообразный рельеф, большое количество кривых участков), и одна из важнейших причин - это фринансовые проблемы. Ключевые слова: высокоскоростные железнодорожные пассажирские перевозки, железнодорожный транспорт, евроинтеграция, качество пассажирских перевозок, инораструктура железнодорожного транспорта.

In the article, it is analyzed the international experience for development of the high-speed railway transportation. The influence of the fasted and high-speed transportations on the attraction of passenger traffic and increase of profit of domestic railways and railways of developed countries is researched. There was a decrease of volumes of transportations tendency almost in all sections of the transport market in Europe on the railways in the end of the 20th century. The only one possibility of railways to increase the passenger traffic was to attract passengers by the speeding up trips, decreasing the time of being on the train and improving the quality of railway services. Problems and perspectives of the high-speed railway passenger transportations implementation in Ukraine has been considered. It is defined, that introduction of the high-speed is the most important way for the passenger and weigh transportations market development on the path to the eurointegration, because eurointegration is the main and unaltered foreign policy priority for Ukraine. And the further development and deepening of relations between Ukraine and the EU is carried out on the principles of political association and economic integration. Based on the analysis it is defined, that the time of the trip is one of the most important factors, that define the demand for the transportation by different kinds of transport, it is decrease has caused a significant increase in passenger traffic in a number of areas. Increase of the passenger traffic demand, certainly, lead to the increase of the frequency for the train connections in the researched directions. Increase of the frequency for the train connections had the "avalanche" effect that appeared as the improving of the transport service quality and this attracted the additional passenger traffic and demanded further increase in the frequency of connections. But nowadays and in the closest future the implementation of the high-speed transportation is going to be problematic. First of all, it is caused by the specific of the high-speed infrastructure, and it's contraction in modern conditions is not a simple task - various terrain, a large number of plot curves and one of the most important reasons are the financial construction problems. In addition, the specifics of the work of transport companies in the field of passenger transportation require a special scientific justification for determining the stages of organization and introduction of high-speed passenger traffic on the railways in Ukraine.

Key words: high-speed railway passenger transportation, railway transport, eurointegration, quality of passenger transportation, infrastructure of railway transport. 
Постановка проблеми. У кінці дев'яностих років минулого століття в Європі на залізницях спостерігалася тенденція до зниження обсягів перевезень практично в усіх секторах транспортного ринку. Єдиною можливістю залізничного транспорту втримати свої позиції з пасажирських перевезень стало залучення пасажиропотоку завдяки підвищенню швидкості руху поїздів, скороченню часу знаходження у путі та поліпшенню рівня комфорту поїздок.

Зараз високошвидкісні сполучення є важливим засобом залучення пасажирів на залізниці у конкурентній боротьбі з іншими видами транспорту, особливо під час перевезень на середні відстані.

Аналіз останніх досліджень і публікацій. Питання впровадження швидкісного та високошвидкісного руху на залізницях України потребують застосування наукового підходу, спираючись на досвід зарубіжних фахівців. Проблеми підвищення швидкостей руху поїздів вивчалися в різних аспектах: технічному, технологічному, соціальному, економічному, екологічному.

У статті досліджено результати наукових досліджень вітчизняних та зарубіжних учених, а саме дослідження історії розвитку європейських високошвидкісних перевезень у працях І.П. Кисельова [1]; Г. Кірпою [2] було викладено основні аспекти впровадження швидкісного руху на залізницях світу; світовий досвід розвитку залізничного транспорту та його перспективи в Україні розглянула О.С. Полтавська [3]; у роботі Н. Божок проаналізовано напрями впровадження швидкісних пасажирських перевезень в Україні та їхні недоліки [4]; аналіз стратегічних орієнтирів інноваційного розвитку залізничного транспорту України зробили І.В. Токмакова, О.В. Хомотюк та Р.О. Новікова [5]. Але деякі питання у цьому напрямі залишаються не вирішеними.

Постановка завдання. Метою статті $€$ дослідження та аналіз упровадження високошвидкісних залізничних перевезень в Україні на основі міжнародного досвіду.

Виклад основного матеріалу дослідження. Високошвидкісні залізничні сполучення базуються на п'яти основних складниках, які в поєднанні забезпечують суттєве підвищення якості транспортних послуг, запропонованих пасажирам:

- інорраструктура;

- високошвидкісний рухомий склад, конструкція та оснащення якого визначають безпеку і коморорт поїздки;

- організація руху потягів та обслуговування пасажирів;

- тарисрна політика;

- чисельність і радіус кривих, а також технічний рівень постійних приладів (систем) тягового електропостачання, сигналізації та зв'язку, що у комплексі визначає можливість руху поїздів із високою швидкістю та, отже, скорочення часу поїздок.

Технологічні досягнення у сорері інфрраструктури та рухомого складу дали змогу суттєво скоротити тривалість поїздки за маршрутами, що входять до мережі залізничних сполучень.

Оскільки час поїздки є одним із важливих чинників, що визначають попит на перевезення тим чи іншим видом транспорту, його зменшення зумовило значне зростання пасажиропотоків за цілою низкою напрямків. Так, наприклад, кількість пасажирів, що користуються залізничним транспортом для поїздок між Парижем і південно-східними районами Франції, зросла приблизно в 2,5 рази за останні 20 років, тоді як кількість пасажирів повітряного транспорту у цьому напрямку скоротилася майже в 2,5 рази, а це є доказом того, що впровадження швидкісного та високошвидкісного руху $є$ необхідним заходом у конкурентній боротьбі між залізничним та іншими видами транспорту.

Також у три рази за шість років збільшилася кількість пасажирів, які користуються залізницею в напрямі Мадрид - Севілья в Іспанії [1].

Після проведення досліджень і соціологічного опитування західні спеціалісти дійшли висновку, що основними користувачами високошвидкісних залізничних сполучень $є$ пасажири:

- які перейшли зі звичайних залізничних сполучень;

- які перейшли 3 повітряного та автомобільного транспорту;

- нові або ті, які збільшили кількість поїздок на маршрутах, що входять у мережу, приваблені швидкістю, коморортом і доступністю сполучень (наприклад, можливістю в той же день повернутися в пункт відправлення).

На відстанях, менших ніж 500 км, із часом поїздки до 2 год 30 хв швидкісні залізничні сполучення мають безперечну перевагу перед повітряними, займаючи в певних випадках до 90\% указаного сегмента пасажирських перевезень, такі як, наприклад, на маршруті Париж - Брюссель, можуть переважати і над поїздками в особистих легкових автомобілях.

Зрештою, поняття «високошвидкісний залізничний транспорт» $є$ умовним і визначається щодо конкретного історичного періоду. Терміни «високошвидкісний транспорт», «високошвидкісний локомотив», «високошвидкісний потяг» використовували вже на початку XX ст., і до цих категорій тоді відносили рух зі швидкістю 150-160 км/год.

На початку Другої світової війни в регулярному пасажирському русі максимальна швидкість найбільш швидкісних поїздів становила 150-170 км/год. Найбільших успіхів досягли тоді в Японії, Великій Британії (з потягами на паровозній тязі), Німеччині та США (з потягами на паровозній тязі й дизель-потягами), у Франції (з легкими авто- 
мотрисами) та Італії (з легкими автомотрисами й електропоїздами).

У період 1950-1960-х років практично в усіх цих країнах здійснювалися інтенсивні науково-дослідницькі та дослідно-конструкторські розробки зі створення нетрадиційних швидкісних систем наземного транспорту 3 використанням монорейкових залізниць, транспортних засобів на повітряній подушці та магнітному підвісі. Досить вражаючими стали перші результати, які були показані колісними монорейковими транспортними системами типів Alweg (Німеччина, Швеція), Skyway (США), SAFEGE (Франція), дослідними потягами на повітряній подушці (аеровагонами) фрранцузького конструктора Ж. Бертена.

Регулярний рух високошвидкісних поїздів почався вперше в 1964 р. в Японії, з 1981 р. - у Франції, з 1984 р. - в Італії. У цих країнах, а такожу Німеччині та Іспанії національні системи високошвидкісного руху засновані на вітчизняному швидкісному рухомому складі, тоді як у низці інших країн, як і в Україні, використовуються іноземні потяги. Західну частину Європи нині об'єднує єдина високошвидкісна залізнична мережа Eurostar i Thalys. На початку XXI ст. світовим лідером у мережі високошвидкісних ліній, а також експлуатантом першого регулярного високошвидкісного маглева (потяг на магнітній подушці) став Китай. Треба відзначити, що Китай володіє найбільшою у світі мережею швидкісних і високошвидкісних залізниць, що перевищує такі в Японії й Європі разом узяті. Середня швидкість руху тут становить понад 200 км/год.

Нині загальна протяжність мережі високошвидкісних залізничних сполучень у світі становить понад 6 тис км, з яких в Японії - 2765 км. 3 урахуванням раніше збудованих і реконструйованих ліній полігон оберту високошвидкісних поїздів перевищує 16 тис км. 31964 р. ними було перевезено понад 7 млрд пасажирів.

Наприкінці XX ст. в Європі на залізницях спостерігалася тенденція до зниження обсягів перевезень практично в усіх секторах транспортного ринку. Винятком стали лише приміські, швидкісні та високошвидкісні пасажирські перевезення. Пасажирські перевезення Америки в більш відчутних масштабах залишилися лише у Північно-Східному коридорі США, а також у сорері приміських сполучень у деяких районах. В Японії розвиток швидкісних пасажирських перевезень дещо уповільнився, але обсяг перевезень на короткі та середні відстані при цьому зростає. Причинами збільшення пасажиропотоку і зростання попиту на пасажирські перевезення залізничним транспортом є збільшення швидкості руху потягів і, як наслідок, зменшення часу на перебування у русі.

Слід відзначити, що сьогодні у світі склалася така градація:
- швидкості до 140 км/год відповідає рух потягів на звичайних залізницях;

- 140-200 км/год - швидкісний рух здебільшого на реконструйованих лініях;

- понад 200 км/год - високошвидкісний рух потягів на спеціально збудованих залізничних магістралях.

Нині в багатьох країнах Європи складено національну мережу високошвидкісного сполучення. Виникла необхідність інтеграції цих мереж в єдину європейську мережу. Розроблення плану інтеграції національних мереж проведено в декілька етапів. На першому етапі (1985-1988 рр.) були підготовлені пропозиції щодо європейської високошвидкісної мережі, які в 1989 р. опублікувала Спілка європейських залізниць (СЄ3). У грудні 1990 р. Рада ЄС ухвалила генеральний план розвитку європейської високошвидкісної сітки. Цей план включив у себе 30 тис км ліній, з яких 9 тис км нових ліній, 15 тис км реконструйованих під швидкість 200 км/год, 1200 км єднальних. Було введено 15 напрямків, які мали особливе значення для європейської мережі, та узгоджено національні проекти. До проектів єднальних ліній можна віднести тунель під проливом Ла-Манш, лінію Барселона - Перпіньян / Монпельє - Ліон Турин, Париж - Брюссель - Амстердам.

Центром мережі стає Берлін, через який проходять пасажиропотоки в напрямку із заходу на схід і назад, а також з півночі на південь. Відкриття тунелю під Ла-Маншем включило до Європейської мережі перевезень і Велику Британію. Перехід Португалії на міжнародний стандарт ширини колії дасть змогу подовжити цю мережу в південно-західному напрямку на 1500 км [2]. А для двох країн, що мають лінії високошвидкісної магістралі, які відрізняються за шириною від основної мережі залізниць (Японії - колія основної мережі - 1067 мм та Іспанії - колія основної мережі - 1668 мм), актуальною є ідея створення потягів, колісні пари яких давали б змогу змінювати положення коліс на осі, що суттєво розширює зону обслуговування пасажирів високошвидкісними поїздами. Першими у світі швидкісними потягами 3 таким улаштуванням колісних пар стали іспанські потяги Talgo, введені до використання ще в 1969 р. Проекти нових потягів із вагонами, які мають розсувні колісні пари, були здійснені протягом останніх років в Японії та Іспанії.

Незважаючи на те, що високошвидкісні залізничні сполучення зароджувалися як внутрішні, нині вони розвиваються і на міжнародному рівні, оскільки мережі високошвидкісних сполучень окремих країн поступово інтегруються, утворюючи мережу, яка розширюється, а динаміка обсягу перевезень пояснюється, головним чином, завдяки постійному розширенню мережі цих сполучень: загальна довжина ліній, які входять у них, збільшилася за цей час майже в три рази. 
Міжнародний проект Північно-Європейської мережі високошвидкісної залізниці з'єднує Велику Британію 3 Францією, Бельгією, Голландією і Німеччиною, зв'язуючи Париж і Лондон із Брюсселем, Амстердамом, Франкоуртом та іншими містами Європи.

У Великій Британії поїздка між Лондоном і Парижем займає дві 3 половиною години. Таким чином, подорож Лондон - Париж - Лондон стала швидшою на 40 хвилин. Потяги Eurostar тепер стануть розвивати на британській ділянці швидкість до 300 км/год. На бельгійській і фрранцузькій ділянках потяги ходять із такою швидкістю вже 10 років. Після впровадження високошвидкісної залізниці до вокзалу Сент-Пенкрас у Лондоні час поїздки до Парижу скоротився до 2 год 15 хв. Компанія Eurostar пов'язує надії на збільшення пасажиропотоку зі зростанням швидкості руху поїздів, оскільки кількість пасажирів у більшу частину минулого року не зростала, що, на думку компанії, пов'язано з економічними та політичними проблемами та скороченням туризму. Проте через конкуренцію з боку авіакомпаній, які продають дешеві квитки, Eurostar потрібно залучати якнайбільше пасажирів, що здійснюють саме ділові поїздки. Ця категорія пасажирів, як відомо, цінує свій час.

Лінія TGV Est-Europeen, уведення якої у 2007 р. дало змогу скоротити час поїдки від Парижа до Страсбурга 34 год до 2 год 20 хв, має особливе значення, тому що європейська лінія дальнього сполучення обладнана новою мультіопераційною системою сигналізації, відомою як ERTMS/ETCS (європейська система керування рухом потягів).

Продовжуються роботи 3 розширення магістралі Париж - Брюссель - Кельн - Амстердам у Бельгії з будівництвом ділянок Лубен - Льєж (62 км) і Антверпен - Голландський кордон (38 км), а також ділянки Льєж - Ахен, доповненої модернізацією лінії Кельн - Дюрен - Ахен. У 2005-2006 рр. поїздка між Кельном і Парижем триватиме вже 3 год 6 хв, а 3 Франкфурта до Брюсселя можна доїхати всього за 2 год 50 хв. У Нідерландах лінія на Брюссель (швидкісна 96-кілометрова гілка) з'єднує бельгійський кордон із Роттердамом

Сьогодні сполучення, які можна розглядати як високошвидкісні, фрункціонують в Японії, Франції, Німеччині, Італії, Іспанії, Швеції, Бельгії, Нідерландах, Фінляндії, Норвегії, Кореї та в Китаї.

Під час проектування нової лінії Токайдо в Японії було враховано тривалість поїздки і зручний графрік руху потягів. Для цього середня швидкість руху повинна бути 200 км/год за максимальної 210 км/ год, при цьому поїздка з Токіо в Осаку займала 3 год 10 хв. Експлуатація цієї лінії за три роки призвела до різкого зростання пасажиропотоку (від 60 до 250 тис відправлених пасажирів за добу). На підставі позитивного досвіду лінії Токіо - Осака було розроблено план будівництва інших ліній із максимальною швидкістю 250 км/год. І в 1970 р. в Японії прийнято закон про створення загальнонаціональної мережі високошвидкісних залізничних ліній, яка отримала назву «Синкансен».

Переваги високошвидкісних магістралей в Японії підтверджені масовим переключенням на них пасажиропотоку 3 автомобільного й авіаційного транспорту.

У Франції до початку Другої світової війни підвищення швидкості досягалося за рахунок зниження числа вагонів до п'яти-семи. Систематичні дослідження й дослідно-конструкторські розробки у сорері високошвидкісного руху здійснювалися $з$ початку 1950-х років. Почалося розроблення проектів упровадження швидкісного пасажирського руху.

Паралельно із цим велися роботи з реконструкції існуючих ділянок, а також їх нове будівництво для високошвидкісного руху. Під час реконструкції існуючих залізниць фрранцузькі спеціалісти керувалися пропозицією, що в майбутньому на цих ділянках буде збережено вантажний рух, а пасажирські потяги будуть ходити зі швидкостями не більше 200-250 км/год. Пізніше було розроблено проект нової залізниці Париж - Ліон для швидкостей до 300 км/год.

Економіка Китаю, що стрімко розвивається, також щільно підійшла до засвоєння високих швидкостей на залізничному транспорті. Спираючись на висловлення офріційних представників Міністерства залізничного транспорту Китаю, головною проблемою $є$ не пошук засобів для будівництва майбутньої високошвидкісної магістралі (за різними оцінками, необхідно близько \$12-15 млрд), а вибір найпередовіших технологій у сорері високих швидкостей [3].

Влада Китаю планує пов'язати країну ще із 17 державами. Це надасть Китаю статусу світового лідера в галузі швидкісних залізничних перевезень, а протяжність високошвидкісних залізничних магістралей у країні перевищить 50\% від загального обсягу подібних магістралей у всьому світі.

У США питання про підвищення швидкостей руху на залізничному транспорті постало у зв'язку 3 потребою населення в пересуванні, яка значно посилилася останнім часом. Понад 80\% усього населення США проживає у містах.

За час експлуатації високошвидкісний залізничний транспорт виявив себе конкурентоспроможним з автомобільним транспортом та авіацією. Адміністрація SNCF уважає, що для сполучення між великими містами за відстані між ними до 1 тис км найбільш доцільним є високошвидкісний залізничний транспорт.

На введених в експлуатацію високошвидкісних магістралях курсують потяги, які відрізняються не 
лише високою технічною швидкістю, а й більш високим рівнем комсрорту.

На шлях підвищення конкурентоспроможності залізничного транспорту з використанням підвищення швидкостей руху стала й Україна. Після проведення досліджень і розрахунків фахівцями економіко-орінансової служби і служб колії залізниць та «Укрзалізниці», а також вивчивши досвід зарубіжних колег, що працювали у цій галузі, швидкісний, а в перспективі й високошвидкісний (за сучасними технологіями) рух планується впровадити на залізницях України.

Перша швидкісна лінія Київ - Харків здана в експлуатацію 11 липня 2002 р., друга - Київ - Дніпропетровськ - 1 серпня 2003 р. Загальна протяжність швидкісних ділянок - 1028 км, на них виконано обсяг робіт на суму близько 200 млн дол. США за рахунок коштів галузі [2]. У 2004 р. відкрито швидкісне сполучення у напрямку Львова і між іншими обласними центрами України. Сьогодні залізницями нашої країни курсує понад 50-ти швидкісних і прискорених потягів із місцями для сидіння підвищеної комфортності далекого і місцевого сполучення, що обслуговуються складами дизель- і електросекцій.

А в січні 2006 р. за маршрутом «Харків - Тополі» почав курсувати рейковий автобус. Він розвиває швидкість до $140 \mathrm{~km} /$ год, оснащений бортовим комп'ютером і може працювати на автопілоті. Річ у тому, що у віддалені та малозаселені райони області $€$ нерентабельним запускання повногабаритних електровозів, а в деякі місця й електропоїзд запустити немає можливості, навіть за наявності рейок, тому що відсутнє електропостачання. Автомобільне ж сполучення є дорожчим і нестабільним (нестабільність погодних умов). А дизель-вагон, як його ще називають, призначений для приміських перевезень пасажирів і, крім того, має більшу кількість позитивних ознак:

- економний режим витрати палива (40 л на 100 KM);

- невисока ціна квитка;

- звукоізоляція в салоні (повна відсутність шуму двигуна й стуку колес);

- комфортабельний салон.

Виготовлено цей рейковий автобус у Польщі, при цьому використано німецькі шасі та шведська електроніка, і коштує він 10 млн грн. Однак уже в 2007 р. Крюковський вагонобудівельний завод розпочав випуск таких вагонів українського виробництва.

Незважаючи на те що швидкісний рух отримав свій розвиток у нашій країні порівняно недавно, однак уже можна помітити досить чуттєві результати.

У цілому попит на перевезення має тенденцію до безперервного зростання, й очікується його зростання в майбутньому. Необхідно також відзначити, що високошвидкісні залізничні сполучення з експлуатаційною швидкістю руху потягів 300 км/год і більше потроху стають звичайним явищем у цивілізованих країнах і набувають усе більшої популярності, насамперед, завдяки високому рівню безпеки. Високошвидкісні магістралі, що знаходяться в експлуатації понад 40 років, за які перевезено більше 6 млрд пасажирів, дотепер залишаються абсолютно безпечними: під час поїздки по ВШМ не загинув жоден пасажир [1].

Створення високошвидкісного рухомого складу вимагає поєднання найпередовіших технологій та високої кваліфікації усіх причетних спеціалістів залізничного транспорту і промислових компаній, неодноразової перевірки технічних рішень і варіантів.

В Україні також планується створення мережі високошвидкісних магістралей із техніко-експлуатаційними параметрами, які забезпечують рух високошвидкісних експресів зі швидкістю 300 км/ год і мають загальну протяжність більше 3 тис км. При цьому необхідно враховувати географрічне положення країни, адміністративний поділ регіонів, розташування міст та економічну ситуацію в країні. Це стало підставою для спеціалістів «Укрзалізниці» для визначення можливих маршрутів високошвидкісних залізничних ліній. Також було здійснено прогноз зміни обсягів пасажирських перевезень, розроблено технічні вимоги для впровадження системи високошвидкісних залізниць в Україні, подано економічну оцінку цим програмам. Запровадження високошвидкісного руху є найважливішим шляхом розвитку ринку залізничних пасажирських та вантажних перевезень.

Це зумовлено, по-перше, необхідністю виведення пасажирських залізничних сполучень на принципово новий якісний рівень, який забезпечить зростання мобільності населення, та, по-друге, необхідністю збереження існуючого пасажиропотоку й залучення додаткових пасажиропотоків, що дасть змогу збільшити прибутки.

Цей крок розвине транзитний потенціал держави від здійснення перевезень і зменшить час на перевезення пасажирів та вантажів у внутрішньому сполученні.

Зважаючи на світовий досвід, для впровадження високошвидкісного залізничного руху необхідно підготувати технічні регламенти, національні стандарти, що містять правила і методи досліджень (випробувань) і вимірювань, відповідну нормативну базу тощо. Ураховуючи, що ПАТ «Укрзалізниця» володіє великим потенціалом, як технічним, так і досвідом розроблення проектів та їх реалізації, товариство має виступати лідером та ініціатором даного питання.

Так, першими напрямками, де могли б реалізуватися технології швидкісного руху, можуть стати сполучення Київ - Одеса, Київ - Львів, а в пер- 
спективі цю роботу можна спрямувати на розвиток сполучення 3 країнами ЄС та інтеграцією української залізничної системи в європейську, зокрема у напрямку Польщі, Австрії, Угорщини [6].

Зараз для України євроінтеграція є головним і незмінним зовнішньополітичним пріоритетом, а подальша розбудова та поглиблення відносин між Україною та ЄС здійснюється на принципах політичної асоціації та економічної інтеграції.

Основними стратегічними документами для досягнення цих цілей є Угода про асоціацію між Україною та Європейським Союзом і Порядок денний асоціації Україна - ЄС.

Угода про асоціацію визначає якісно новий формат відносин між Україною та ЄС і $€$ стратегічним орієнтиром системних соціально-економічних редорм в Україні.

Сучасні швидкісні поїзди на залізницях України - це кардинально інший погляд на рівень якості перевезення пасажирів та надання сервісних послуг. Українська залізнична швидкісна компанія була заснована 22 лютого 2012 р. для організації швидкісного руху на теренах України. Нині Українська залізнична швидкісна компанія - єдиний державний оператор пасажирських залізничних перевезень, в експлуатації якого знаходиться новітній рухомий склад.

Мережа маршрутів Української залізничної швидкісної компанії має дуже широкий спектр. Зараз вона об'єднує Київ із найбільшими промисловими центрами України, такими як Запоріжжя, Дніпро, Харків, а також культурними центрами історичного регіону Галичини: Львовом та Тернополем. Не $є$ винятком і перлини вітчизняного курортного відпочинку Трускавець та Одеса.

Міністерством інфраструктури України було розроблено законопроект «Національна стратегія - 2030 Drive Ukraine", який було внесено до парламенту. Стратегічна мета цього законопроекту - інтеграція України у світову економіку та технологічний стрибок у сфері інфраструктури [7].

Але в найближчий час у залізничній галузі України впровадження високошвидкісних перевезень (до 300 км/год), ймовірно, буде проблематичним. Це, перш за все, викликане специсрікою інорраструктури на таких швидкостях, а побудова її в умовах України не є простим завданням (різноманітний рельєор, велика кількість кривих ділянок), та однією 3 найважливіших причин $€$ фрінансові проблеми побудови.

Висновки 3 проведеного дослідження. Під час виходу України з кризи й стабілізації політичного і фрінансового становища країни та залізничного транспорту зокрема, коли постане питання про впровадження високошвидкісного пасажирського руху, доцільне впровадження високошвидкісного залізничного пасажирського руху з урахуванням міжнародного досвіду його розвитку. Але необхідно враховувати географрічне положення країни, адміністративний поділ регіонів, розташування міст та економічну ситуацію в країні. До того ж специсріка роботи транспортних підприємств у сорері пасажирських перевезень потребує спеціального наукового обґрунтування щодо визначення етапів організації та впровадження швидкісного пасажирського руху на залізницях саме в Україні.

\section{БІБЛІОГРАФІЧНИЙ СПИСОК:}

1. Кисилев И.П. Краткий обзор истории европейских высокоскоростных поездов. К итогам конгресса EurailSpeed 2005. Железные дороги мира. 2006. № 1. C. 18-41.

2. Железные дороги мира в XXI веке / под общ. ред. Г.Н. Кирпы. Днепропетровск : Днепропетровский национальный университет железнодорожного транспорта им. Лазаряна, 2004. 236 с.

3. Полтавська О.С. Світовий досвід розвитку залізничного транспорту та перспективи його розвитку в Україні. Вісник Національного університету «Львівська політехніка». Менеджмент та підприємництво в Україні: етапи становлення і проблеми розвитку. 2014. № 797. С. 470-476. URL : http://nbuv. gov.ua/UJRN/VNULPM_2014_797_64pdf (дата звернення: 08.07.2019).

4. Божок Н.О. Напрями впровадження швидкісних пасажирських перевезень в Україні. Проблеми економіки транспорту. 2013. № 5. С. 46-56.

5. Токмакова І.В. Стратегічні орієнтири інноваційного розвитку залізничного транспорту України. Вісник економіки і промисловості. 2016. № 55. С. 75-77.

6. Основні аспекти стратегії розвитку ПАТ «Укрзалізниця» 2017-2021 роки. URL : http://agreca.ua/ oprilyudneno-osnovni-aspekti-strategiyi-rozvitku-patukrzaliznitsya-na-2017-2021-roki (дата звернення: 07.07.2019)

7. Національна транспортна стратегія до 2030 року "Drive Ukraine 2030». URL : https://mtu.gov.ua/ files/projects/str.html (дата звернення: 08.07.2019).

\section{REFERENCES:}

1. Kisilev I.P. (2006) Kratkyj obzor ystoryy evropejskykh vusokoskorostnukh poezdov. K ytogham konghressa EurailSpeed 2005 [A brief overview of the history of European high-speed trains. The results of the EurailSpeed 2005 Congress]. Railways of the world, no. 1, pp. 18-41.

2. Kirpa G.N. (ed.) (2004) Zheleznue dorohy myra $v X X I$ veke [Railways of the world in the XXI century]. Dnipro : Dnepropetrovskyi natsyonalnui unyversytet zheleznodorozhnoho transporta ym. Lazoriana, p. 236. (in Ukrainian).

3. Poltavskaya O.S (2014) Svitovyi dosvid rozvytku zaliznychnoho transportu ta perspektyvy yoho rozvytku $\checkmark$ Ukraini [World experience of race transport development and its prospects of development in Ukraine]. Visnyk Natsionalnoho universytetu "Lvivska politekhnika". Menedzhment ta pidpryiemnytstvo v Ukraini: etapy stanovlennia i problemy rozvytku [Bulletin of the 
National University "Lviv Polytechnic". Management and entrepreneurship in Ukraine: stages of formation and development problems] (electronic journal), no. 797, pp. 470-476. Available at: http://nbuv.gov.ua/UJRN/ VNULPM_2014_797_64 (accessed 03 July 2019).

4. Bozhok $\bar{N} . O . \overline{(2013)}$ Napriamky vprovadzhennia shvydkisnykh pasazhyrskykh perevezen v Ukraini [Ways for introduction of high-speed passenger transportation in Ukraine]. Collection of scientific works of Dnipropetrovsk National University of Railway Transport named after academician V. Lazaryan "Problems of Transport Economics", no. 5, pp. 46-56.

5. Tokmakova I.V., Khomotiuk O.V., Novikov R.O. (2016) Stratehichni oriientyry innovatsiinoho rozvytku zaliznychnoho transportu Ukrainy [Strategic guide- lines for innovative development of railway transport of Ukraine]. Bulletin of Economics and Industry, no. 55, pp. 75-77.

6. Osnovni aspekty stratehii rozvytku PAT "Ukrazilznytsia" 2017-2021 roky [The main aspects of the development strategy of Ukrazilznytsia PJSC are 2017-2021 years] (electronic resource), Available at: http://agreca.ua/oprilyudneno-osnovni-aspekti-strategiyi-rozvitku-pat-ukrzaliznitsya-na-2017-2021-roki (дата звернення: 07 July 2019).

7. Natsionalna transportna stratehiia do 2030 roku "Drive Ukraine 2030» [National transport strategy until 2030 "Drive Ukraine 2030»] (electronic resource), Available at: https://mtu.gov.ua/files/projects/str.html (accessed: 08 July 2019). 
Yeromina Marina

Candidate of Economic Sciences,

Senior Lecturer at Department of Management of State and Corporate Finance

Ukrainian State University of Railway Transport

Troynikova Elena

Candidate of Economic Sciences, Senior Lecturer at Department of Management of State and Corporate Finance Ukrainian State University of Railway Transport

Sapronova Olha

Student

Ukrainian State University of Railway Transport

\section{ANALYSIS OF INTERNATIONAL EXPERIENCE FOR THE DEVELOPMENT OF HIGH-SPEED RAILWAY TRANSPORT AND QUESTIONNAIRE OF ITS IMPLEMENTATION IN UKRAINE}

The purpose of the article. The purpose of the study is to research and analyze the implementation of high-speed rail transportation in Ukraine based on international experience.

Methodology. The methodological basis of the study is a dialectical approach to the consideration of economic phenomena and contradictions; systematic analysis of international experience and problems of introduction of high-speed railroad traffic in the field of passenger transportation and features of its application in Ukraine.

The information base of the study is the legislative and normative acts of Ukraine on rail transport; European Railway Law; data of the Railways Cooperation Organization; Reviews of the economic situation of the transport industry.

Results. As travel time is one of the important factors determining the demand for transportation by this or that mode of transport, its reduction has caused a significant increase in passenger traffic in a number of areas. Thus, the introduction of high-speed and high-speed traffic is very relevant to the transport industry of almost all developed countries of the world. Ukraine is no exception.

Increase of the passenger traffic demand, certainly, lead to the increase of the frequency for the train connections in the researched directions. Increase of the frequency for the train connections had the "avalanche" effect that appeared as the improving of the transport service quality and this attracted the additional passenger traffic and demanded further increase in the frequency of connections.

At present, a national high-speed network has been created in many European countries. There was a need to integrate these networks into a united European network. The center of the network becomes Berlin, through which passage flows in the direction from west to east and back, as well as from north to south.

After conducting research and calculations by experts of the economic-financial service and railroad services and Ukrzaliznytsia, as well as studying the experience of foreign colleagues working in this field fasten, and in the long run, high-speed (by modern technologies), the movement is planned to be implemented on the railways of Ukraine.

Eurointegration is the main and unaltered foreign policy priority for Ukraine. The further development and deepening of relations between Ukraine and the EU is carried out on the principles of political association and economic integration.

Passenger traffic and demanded further increase in the frequency of connections.

Nowadays and in the closest future the implantation of the high-speed (up to $300 \mathrm{~km}$ per hour) transportation is going to be problematic. First of all, it is caused by the specific of the high-speed infrastructure, and it's contraction in modern conditions is not a simple task - various terrain, a large number of plot curves and one of the most important reasons are the financial construction problems

Practical implications. When Ukraine emerges from the crisis and stabilizes the political and financial situation of the country and railway transport, in particular when it comes to introducing a high-speed passenger movement, it is advisable to introduce a high-speed railway passenger traffic taking into account of the international experience of its development. It is necessary to take into consideration the geographical position of the country, the administrative division of regions, the location of cities and the economic situation in the country.

Value/originality. In this work, the research and analysis of the experience and problems of the introduction and development of high-speed passenger railway traffic in developed countries of the world, which is appropriate and necessary to be applied in Ukraine. But it is necessary to take into account that the specifics of transport companies in the field of passenger transportation requires a special scientific substantiation regarding the definition of the stages of organization and introduction of high-speed passenger traffic on the railways in Ukraine. 